\title{
NARRATIVE MODES, NARRATIVE SPACE, AND NARRATIVE PLAY IN THE POST-CLASSICAL SAGAS AND PAETTIR OF ICELANDERS
}

\author{
LUCIE KORECKÁ
}

\begin{abstract}
Scholars have traditionally viewed the post-classical sagas and poettir of Icelanders, written between the second half of the 13th century and the early 15 th century, as inferior to the classical sagas and poettir in terms of narrative form and social relevance. In the present study we argue that the post-classical texts show an innovative approach to the concept of narrative space, and that they are reflective of the various narrative modes in a way that allows the narratives to become more varied and multi-layered than the classical sagas. We also argue that the increased use of supernatural motifs is not a sign of disinterest in the social concerns, because such motifs contribute to the conceptualization of the social issues that had changed after the end of the Sturlung Age, but they had not become less significant.
\end{abstract}

Keywords: Old Norse literature; narratology; sagas of Icelanders

1.

Unlike the classical sagas and poettir of Icelanders, which have been the most broadly studied group of Old Norse texts, their post-classical counterparts, written between the second half of the 13th century and the early 15th century, have received little attention within the saga research. The reason is mostly the fact that many scholars have viewed the post-classical narratives as inferior to the classical texts in two respects. Firstly, it has been stated that their narrative structure is distorted by random borrowings of motifs from the legendary sagas, saga romances, and folklore (Sveinsson 1953, 124-125; Faulkes 269; Hallberg 1964, 129-130; Nordal 1953, 261; Schach 27; Einarsson 150-151). Secondly, they have been criticized for turning from serious social concerns to pure fabulation, which serves only the purpose of thoughtless entertainment (Sveinsson 1958, 125-126; Gordon lv-lvi; Hallberg 1962, 145). This negative evaluation of the post-classical texts in research was shaped by the contemporary literary and political environment (Arnold 49-52), rather than by a deep insight into the narrative principles and social functions of medieval literature. The perception of saga literature was formed by the current literary 
taste, which favoured the realistic novel at the time when saga studies underwent their decisive development (Arnold 7-8, 52-53, 93-95); the criteria created in this environment continued to influence saga studies for a long time. On the political level, saga studies were influenced by Iceland's struggle for independence from Denmark in the late 19th and early 20th centuries. Icelandic saga scholars of that time utilized the sagas' idealized image of independent Icelandic society in the political debate, and the classical sagas with their realistic tone and focus on the social structures doubtlessly served this purpose best (Arnold 71-85, 102-106). This tendency was also retained after the successful ending of the independence struggle. In line with it, the aforementioned scholars have mostly associated the alleged decline of literary taste with the assumption that Iceland's union with Norway in 1264 meant a downfall of the Icelandic society (Sveinsson 1953, 1-5, 22, 59-60; Hallberg 1962, 144-146; Nordal 1942, 340-341).

The post-classical sagas have finally received some degree of increased scholarly attention in the recent decades, but an extensive re-evaluation of their narrative principles and social functions is still missing. The only existing monograph on these texts (Arnold) suggests some inspiring new approaches, but it is still largely formed by the idea that Iceland's union with Norway turned literature away from social concerns and transformed it into a response to older literature with strong elements of deconstruction and parody, ${ }^{1}$ as if consciously fictional literature could not also represent a conceptualization of significant social issues. This view will be challenged in the present study.

Other recent studies often show that scholars are still confused by the narrative principles of the post-classical sagas and, being unable to explain these principles, mark the texts as "generic hybrids" (Cardew 18) and retain the older idea that the texts were originally classical sagas, to which the post-classical elements were added later (Cardew 19). The argumentation for such a development is not convincing, and this direction in research has not contributed to a better understanding of the post-classical sagas' structure, meaning, or social significance. ${ }^{2}$

Some studies that are free from such misleading preconceptions have also appeared (Jakobsson), but they mostly focus on specific aspects of individual sagas' meaning, and their findings, contributive as they are, do not answer most of the questions that surround the post-classical sagas as a group. Furthermore, even these studies tend to understand the post-classical sagas too literally, rather than revealing the metaphors and symbolism in them. In his study of Bárðar saga Snæefellsáss, Ármann Jakobsson suggests that a medieval narrative can be both historical and fictional if we assume that the author believed in the existence of trolls $(1998,54)$. While such an assumption is not exactly wrong, I will argue in the following that it is more fruitful to regard even openly fictional texts as metaphorical commentaries on the time of their composition.

1 Arnold speaks of "a dialogue with a number of classical Îslendingasögur" (208), and he claims that the classical sagas constitute a creation myth of the Icelandic nation, but the post-classical sagas "undermine the credibility of the idealising narrative myths of the classical saga" (226). Finally, he directly states that "the discourse of the post-classical Îslendingasögur is not directed at a sense of objective reality, or at a world in which societal problems are enacted and solved, rather it is directed [...] at the pre-established discourse of the classical saga" (231), and that the post-classical sagas are "an act of cultural deconstruction as opposed to an act of cultural reconstruction" (241).

2 For criticism of the idea of the supernatural elements being later interpolations, see also Sävborg 2012a: $40-50$. 
Vésteinn Ólason (2007) is right in pointing out the increased significance of supernatural elements for the main story line of the post-classical sagas, and in associating this development with the political and social changes in Iceland. What is missing in his study is an overall analysis of the post-classical sagas' narrative structure and of the supernatural elements' diverse functions within this structure; he does not go further than pointing out that the structure is episodic and the fantastic is decisive for the plot.

The most extensive studies of supernatural motifs in the post-classical sagas have been carried out by Daniel Sävborg. He has challenged the idea that supernatural motifs in the post-classical sagas are borrowings from the legendary sagas (fornaldarsögur), which was previously mostly taken for granted (Sävborg 2012b). That is an innovative approach, which needs to be taken into account in all subsequent studies, but in itself it reveals little about the narrative function of the supernatural motifs in the sagas, or about the specificness of the post-classical sagas as opposed to the classical ones.

As a defining criterion for the distinction between the classical and post-classical sagas of Icelanders, Sävborg (2009) hypothetically suggested the presence or absence of the so-called distance markers (distansmarkörer), a set of story elements and narrative devices that mark encounters between the human and the supernatural as abnormal or shocking and underline the physical distance, thus emphasizing the boundary between the human and supernatural world. This hypothesis, however, did not prove true in his study, and he concluded that the presence or absence of distance markers depends on whether the scene takes place in Iceland or abroad, and that this applies to both the classical and post-classical texts $(2009,344-346)$. That is doubtlessly true, but it does not imply any satisfactory solution to the problem of what defines the difference between the classical and post-classical sagas of Icelanders in terms of narrative principles. I believe that the reason is that the study focuses on individual episodes that contain supernatural motifs, and it does not pay enough attention to the sagas' overall narrative structure and to the roles that the supernatural elements play in the construction of this structure.

The question to be asked here is what the decisive criterion for the distinction between the classical and post-classical sagas is. It has already been shown that it is not the presence or absence of distance markers. It is not the number of supernatural elements either, as some post-classical sagas contain fewer of them than some of the classical sagas, such as Eyrbyggja saga. In the following I will argue that what really marks the difference between the two groups of texts is their different narrative form, based on different emphases in the meaning and different approaches to the functions of supernatural motifs. This difference does not, however, mean that the post-classical narratives are less meaningful or less sophisticated. Far from employing the supernatural motifs randomly, the post-classical narratives work with them more systematically than the classical texts, and they follow specific narrative principles, which are meaningful in a literary perspective, as well as in a social context.

2.

The theoretical background for the present approach to the texts is based on the idea that the fantastic cannot be isolated as a separate genre or form, because all literature is 
a product of both the mimetic and the fantastic impulse, both of which are structural elements that are combined in different ways in various genres (Hume 1984). This is true for many kinds of literature of diverse genres, both medieval and modern.

For studying the Icelandic sagas specifically, we can formulate three narrative modes: realistic, adventurous, and fantastic. The main differences between them are not primarily based on their relation to objective reality, but rather on the principles that define their narrative structure. All the modes may contain supernatural motifs, but their narrative function is different.

In the realistic mode, typical for the classical sagas of Icelanders and kings, the defining principle of the narrative structure is causality, and the structure is linear.

\section{cause $\longrightarrow$ action $\longrightarrow$ consequence}

The mimetic and fantastic impulse are intertwined, and the supernatural motifs are not involved in the main story line, they occur only in individual episodes. For example, the revenant Pórólfr in Eyrbyggja saga is presented only in a short episode in chapter 34, which is not a part of the main story line. He briefly reappears in the episode with the monstrous bull Glæsir in chapter 63, but as soon as the supernatural motifs disappear, the narrative turns back to the main story line. Supernatural elements are often used as means of foreshadowing or as explanations of events that have no logical reasons, as the narrative structure of this mode requires an explanation for everything. The ominous gandreið in Njáls saga only predicts the sinister events that are about to happen, but their real cause is carefully explained in terms of conflicts within the society. Similarly, porgrímr's sorcery in Gísla saga is used to explain Gísli’s extreme misfortune, but his outlawry is an outcome of a long and complex chain of cause and consequence.

In the adventurous mode, typical for the legendary sagas (fornaldarsögur), chivalric sagas (riddarasögur), and saga romances (lygisögur), the defining principle of the narrative structure is a pattern based on an ideal and a reward, and the structure is episodic.

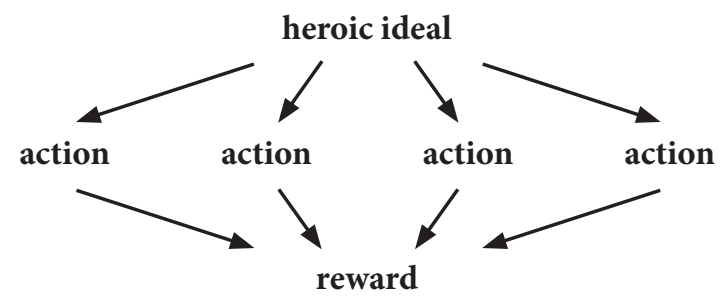

The main reason for the hero's quests is his wish to test his strength and gain glory, and the quests are usually only loosely connected to each other, but all of them together lead to a reward. The boundaries between the mimetic and fantastic impulse are stretched and tested. The hero's strength is improbable, but not impossible, exaggerated rather than supernatural. Supernatural creatures are an inseparable part of the protagonist's narrative space, so we cannot speak of any crossing of boundaries. The monsters play the role of clearly defined evil, and the hero stands in the clearly defined position of their defeater. The sagas that are set entirely in this mode do not primarily focus on Icelandic social 
concerns, but in combination with the other modes, this mode can provide a contrast that highlights the saga's message.

In the fantastic mode, typical for the post-classical sagas in combination with the other two, the defining principle of the narrative structure is a distortion of balance by a supernatural intervention and a re-establishment of the balance by a supernatural counteraction. The structure is cyclical.

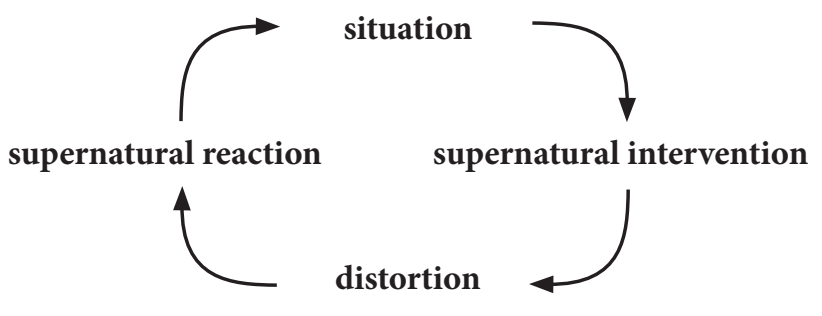

A supernatural intervention can unexpectedly distort any situation, and its consequences cannot be averted by normal human action, only by another supernatural force. If the supernatural force is absent in the counteraction, the balance remains disrupted. The mimetic and fantastic impulse create a contrast, underlining the contact between the human world and other worlds - the world of dreams, the dead, mythical forces, and supernatural creatures. These elements constitute a specific narrative space that creates different expectations. The plot is based on crossing the boundaries between the narrative spaces, and the supernatural motifs play a central role in the main story line. ${ }^{3}$

The classical sagas and poettir of Icelanders and kings, as well as the legendary sagas (fornaldarsögur) and saga romances (lygisögur), are based on one dominant narrative mode, while the other two are absent or strongly suppressed. The narrative space of these texts is mostly uniform, and the crossing of boundaries between various spaces is either absent, or it plays only a marginal role in the story. In the classical sagas of Icelanders or kings, the main story line is usually concerned with the natural human world defined by the law, and contacts with other worlds occur only in individual episodes. In the legendary sagas and other fantastic saga subgenres, the boundaries between the natural and the supernatural are so vague that it is usually impossible to attribute any noticeable narrative function to them.

In the post-classical sagas and poettir, on the other hand, all the three modes are combined, but the combination is not random. The transitions from one mode to another are reflected in the narratives, and such conscious work with the modes makes the resulting narratives more varied. The different narrative spaces form interesting contrasts, and the theme of crossing boundaries between them not only creates a multi-layered narrative, but also plays a significant role in constructing the text's meaning. In the following we will illustrate this on two post-classical poettir and three post-classical sagas of Icelanders.

3 The significance of supernatural motifs for the main story line in the post-classical sagas has already been pointed out by Arnold 145 and Ólason 15. The theory of the narrative modes aims at providing a deeper understanding of these motifs' significance for the forming of the texts' structure and meaning. 
Orms páttr Stórólfssonar is a short tale about an Icelander, composed around 1300 and preserved in the manuscript Flateyjarbók (GkS 1005 fol.) from around 1390. The story begins in the realistic mode with the settlement of Iceland by Ormr's ancestors. Everything that happens in this section is explained by rational causes, and no supernatural motifs are found here. Ormr's life then gradually shifts into the adventurous mode, when he seeks opportunities to show off his almost superhuman strength, instead of using his muscles in farmwork. The adventurous mode becomes fully developed when Ormr travels to Norway, where he gets an equally heroic fosterbrother Ásbjörn and they undertake some adventures typical for this mode, such as raiding expeditions. The protagonists are characterized by some hardly believable traits, but they cannot be regarded as supernatural - real human qualities, such as strength and courage, are only exaggerated to their limits.

Ásbjörn's story forms a partly individual story line, which is set on the border between the adventurous and fantastic mode. His journey to the ogre is motivated by his desire to gain glory and to defy his fate, which is a situation known from some of the legendary sagas set in the adventurous mode, such as Örvar-Odds saga. This section focuses on the notion of fate, which is underlined by a prediction that is disregarded by the hero; both the prophecy and the hero's disdain are emphasized by stanzas. The hero then becomes so eager to prove the prediction wrong that he deliberately breaks the ban uttered by the seeress, thus paradoxically causing the fulfilment of the prediction, which is again underlined by a sequence of stanzas, the so-called death song. In the hero's encounter with the otherworldly creature, the narrative does not entirely shift into the fantastic mode, because the supernatural counteraction is absent; Ásbjörn is therefore defeated and the balance is not re-established.

The fantastic mode takes fully over in the episode of Ormr's revenge expedition. Ormr is visited in a dream by a supernatural woman, who gives him magic gloves; with the help of this magic gift he manages to enter the giant's cave. Finally, at the most difficult moment of his duel with the giant, Ormr calls on the Christian God, and the divine power helps him defeat the giant. The balance is restored, the supernatural evil subsides, and the story returns into the adventurous mode again when Ormr's strength is tested by the earl's men; again we see the motif of almost superhuman abilities that can still not be regarded as supernatural. Finally, the story returns to the realistic mode when Ormr returns to Iceland and lives there as a respectable man.

The modes thus shift in a circle, in which the fantastic mode forms the central point of the narrative and is followed by a gradual return into the realistic mode. The transitions between the modes are marked by specific narrative elements. The adventurous mode is typically marked by a journey abroad, where the hero can use his abilities better than in Iceland. The fantastic mode is introduced by a dream, which has a specific function. It does not merely foreshadow future events, but it directly influences them, because the hero keeps the magical objects gained in the dream after waking up. This implies a transition into a supernatural world, governed by its own rules. During the hero's return the modes are again marked by a journey back to the earl's court and then to Iceland.

It is not only the frequency and intensity of the supernatural motifs that changes from mode to mode, but mostly their function. Only in the fantastic mode, which forms 
the decisive moment of the story, is the action transferred into a world where the laws and rules of our everyday life do not apply, dreams can be directly connected to reality, a mortal can temporarily gain supernatural powers, and a deity can directly influence the action. Due to this, the balance can be restored after a supernatural intervention. The gradual, cyclical shifting of the modes makes the story distinctly dynamic, which is something that would be difficult to achieve within a single mode. At the same time, however, the modes are firmly connected and form a coherent, well-structured narrative.

Even more interesting narrative devices with metafictional elements can be found in a páttr known as Stjörnu-Odda draumr, dating with all probability from the 14th century. It was a part of the manuscript Vatnshyrna, which is believed to have been written around 1390 and was destroyed in the Copenhagen fire of 1728. The text is now preserved only in modern copies, some of which claim to have been copied directly from Vatnshyrna. The fact that this text, due to its specific narrative structure, is one of the earliest Icelandic examples of open literary fiction, has already been pointed out by Ralph O'Connor (474-483, 504-512); in his study he focuses on the roles of dreams and visions in medieval literature, and on the motif of an astronomer, rather than on the narrative roles of supernatural motifs, and he does not imply how his findings about Stjörnu-Odda draumr can be applied to the research of the post-classical sagas. That is what will be attempted here.

The beginning of the páttr is set in the realistic mode, featuring an everyday situation and the probably historically real figure of Oddi Helgason. ${ }^{4}$ The introductory paragraph emphasizes that Oddi is not a poet and cannot compose stanzas. Such information seems unnecessary, but it cleverly prepares the ground for what is to come later in the narrative. The text continues with Oddi going to sleep while he is away from home and having a dream. In the first part, Oddi dreams that he is at home and a guest there is asked to tell a story about an ancient king of Gautland. That is to say that the story does not happen in the dream, it is told in the dream, so there is a double distance between the narrative space of the frame story and that of the heroic story:

\begin{tabular}{|c|c|c|}
\hline narrative space 1 & narrative space 2 & narrative space 3 \\
\hline frame: & narration: & story: \\
\hline $\begin{array}{c}\text { the farm where Oddi } \\
\text { is sleeping }\end{array}$ & $\begin{array}{c}\text { the dream: Oddi is at home } \\
\text { listening to a story }\end{array}$ & $\begin{array}{c}\text { the ancient tale told } \\
\text { in the dream }\end{array}$ \\
\hline (Iceland) & (Iceland) & (Gautland) \\
\hline
\end{tabular}

The story told in the dream begins like a typical heroic saga about a young king who wishes to test his strength and gain some glory. This section of the narrative is set in the adventurous mode and features some of its typical signs, such as exaggerated courage and a quest motivated by the ideal of honour.

4 Stjörnu-Oddi Helgason is believed to have been a real historical figure living in the late 11th- and 12th-century Iceland (ca. 1070/80 - ca. 1140/50). He was with all probability the author of Oddatala, a work of remarkable astronomical knowledge achieved through careful observations. In Oddatala he stated the position of the sun for every day of the year in Iceland and calculated the dates of summer and winter solstices. 
Not far into this story, the narrative describes a change in the dream: now Oddi does not dream that the story is told to him, but that he is one of the characters, the king's court poet Dagfinnr. This means that now he is inside the dream story and he is not himself, but somebody else. The change is directly commented on by the narrator:

En pegar pessi maðr Dagfinnr var nefndr í sögunni, pá er frá pví at segja, er mjök er undarligt, at pá brá pví við í drauminum Odda, at hann Oddi sjálfr póttist vera pessi maðr Dagfinnr, en gestrinn sá er söguna sagði er nú ór sögunni ok drauminum, en pá póttist hann sjálfr sjá ok vita allt pat er héðan af er í drauminum. En nú síðan er drauminn svá at segja, sem honum pótti sjálfum fyrir sik bera, Odda, pá póttist pann vera Dagfinnr ok ráðast í ferðina með konunginum Geirviði.

[But as soon as this man, Dagfinnr, was named in the story, it is to be said - strange as it is - that a change occurred in Oddi's dream, and that it now seemed to him that he himself had become this Dagfinnr, but the guest who told the story is now out of the saga and of the dream. It seemed to Oddi that he himself saw and knew everything that happened in the dream from then on. So now the dream is to be told as it appeared to Oddi; he dreamt that he was Dagfinnr and set out on a journey with King Geirviðr.]

This commentary emphasizes the change of relations between the narrative spaces:

\begin{tabular}{|c|c|}
\hline narrative space 1 & narrative space 2 \\
\hline frame: & story: \\
\hline the farm where Oddi is sleeping & $\begin{array}{c}\text { Oddi/Dagfinnr takes part in the heroic action } \\
\text { in the dream }\end{array}$ \\
\hline
\end{tabular}

The story continues with the king fighting and defeating two berserkers. The poet accompanies him, but he does not take part in the fight and afterwards composes a poem about it. The poem is not quoted at this place in the narrative. This part of the dream is still set in the adventurous mode; it is a heroic story without supernatural elements, only with some degree of heroic exaggeration.

In the next part of the dream story, the king is challenged to a battle by the female viking Hlégunnr; before the battle Dagfinnr ties his shoe and at that moment Oddi wakes up and is himself again. He remembers some of the stanzas from the dream, which are now quoted in the narrative. It is certainly not an unusual motif in Old Norse literature that a character wakes from a dream and recites some stanzas related to the dream; many examples can be found. The main difference here is that the stanzas from the dream are not connected in any way to the real life of the character - they do not predict or comment on anything that happens to Oddi outside of the dream. Remembering the statement that the real Oddi never composed any stanzas, we are assured that he really was somebody else in the dream. If Dagfinnr had recited the stanzas to the king within the dream story, they would have been nothing more than a part of this heroic story. By being recited after waking up, however, they gain the function of a link between the story and the frame, but as such they only underline the distance between the two. We can thus speak of two separate narrative spaces, connected on the narrative level by the means of stating that one of them exists in a dream. The break in the dream when Oddi wakes up 
serves to remind the audience of this specific intertwining of the two narrative spaces. Furthermore, this repeated reference to the dream marks a transition into the fantastic mode - this can indeed be regarded as the main purpose of the reference.

The narrative continues with Oddi falling asleep again. In the second dream, Oddi is Dagfinnr again and takes part in the battle. The story is now set in the fantastic mode. The balance is disrupted by Hlégunnr's supernatural abilities, which enable her to change shape, so that she now has a wolf's head. The disruption causes the always victorious king to almost lose the battle. This is, however, followed by a supernatural counteraction. Dagfinnr has the ability of seeing the magically concealed Hlégunnr, tells the king how he can see her despite her magic, and as soon as the king is able to see her, he kills her. When she is dead, the supernatural element disappears from the story, the balance is re-established, and the king wins the battle.

Dagfinnr now composes a better poem, a drápa; it is not quoted immediately. As a reward for his courage in the battle and for the poem he gets to marry the king's sister. Then the dream ends and Oddi wakes up and is himself again; he remembers both parts of the dream and some of the stanzas from the drápa, which are quoted only now. The dream-story is finished with an ending that is quite typical for the heroic tale - the hero has proven his worth and gained a reward. The ending of the frame story, on the other hand, is unusual and can indeed be regarded as metafictional:

Nú er draum pessum lokit er Stjörnu-Odda dreymdi eptir pví sem hann sjálfr hefir sagt, ok má víst undarligr ok fáheyrðr pykkja pessi fyrirburðr, en pó pykkir flestum líkligt at hann muni pat eina sagt hafa, er honum hafi svá pótt verða í drauminum, pví at Oddi var reiknaðr bæði fróðr ok sannsögull; má ok ekki undrast pótt kveðskaprinn sé stirðr, pví at í svefni var kveðit.

[Here ends the story of the dream of Star-Oddi as he himself told it. These events certainly seem strange and unheard-of, but still most people believe that he told his dream the way he had dreamt it, because Oddi was regarded as a wise and truthful man. And it is no wonder that the stanzas are not too fluent, as they were composed in sleep.]

Here the narrator steps boldly forward to excuse the two faults of his narrative: that it is too fantastic and unbelievable, and that the stanzas are not metrically perfect. The structure of the narrative thus becomes unusually sophisticated, consisting of four layers:

\begin{tabular}{|c|c|c|c|}
\hline narrative space 1 & narrative space 2 & narrative space 3 & narrative space 4 \\
\hline metatext: & frame: & narration: & story: \\
\hline $\begin{array}{c}\text { the narrator referring } \\
\text { to Stjörnu-Oddi as his } \\
\text { source }\end{array}$ & $\begin{array}{c}\text { Oddi sleeping, waking } \\
\text { and remembering the } \\
\text { dream }\end{array}$ & $\begin{array}{c}\text { the story told in the } \\
\text { dream }\end{array}$ & $\begin{array}{c}\text { action experienced by } \\
\text { Oddi/Dagfinnr in the } \\
\text { dream }\end{array}$ \\
\hline
\end{tabular}

Unlike the dreams in the realistic mode, which foreshadow future events or reveal a character's emotions, the dream in this text marks the boundaries between the narrative spaces and modes, and it contributes to the narrative's metafictional character. This makes the text unexpectedly advanced and "modern" in a manner that cannot be found in the classical sagas. The páttr employs stereotypical narrative elements known from the classi- 
cal sagas, such as dreams, stanzas, and supernatural motifs, but it combines and modifies them in unusual ways, which we can label with the term "narrative play".

In the following we will analyse different kinds of narrative play in longer post-classical texts, in which the narrative conventions known from the classical sagas are twisted in multiple ways, but always deliberately and purposefully.

\section{4.}

In many of the post-classical sagas, the narrative function of the supernatural motifs is modified in accordance with the mode that prevails in any given section. We start by illustrating this on Svarfdoela saga, a text preserved only in 17th-century paper copies of late medieval manuscripts, with the exception of one 15th-century folio. In this saga, the sections narrated in the adventurous mode, describing viking expeditions and fights with champions and berserkers, contain no truly supernatural elements, whereas the parts narrated in the realistic mode and describing typical saga feuds and local conflicts feature the motif of a revenant participating in the events. The character named Klaufi is a fierce, reckless man, a viking's son, who is clearly better suited for heroic adventures than for local disputes in Iceland. Nevertheless, he stays in Iceland and participates in the local feuds, which remain set in the realistic mode. Klaufi, however, creates a specific narrative space he does not respect the rules of the realistic mode and brings in elements of the adventurous mode, but a full transition into the adventurous mode does not occur. The presence of this conspicuous character underlines the contrast between the two modes.

Klaufi gets into a conflict with another man over a woman and gains her, but in the end she betrays him and lets her brothers kill him. After the killing, Klaufi becomes a revenant, and he not only incites his kinsman to avenge him, but also actively takes part in the fight. After this fight the conflict continues; the undead Klaufi reappears in a vision to warn his kinsman about an upcoming fight, which is another attempt at actively changing the course of action. His cousin does not heed the warning, he is killed in the fight, and the killing is later avenged in a standard saga way, without any supernatural interventions. Finally, the undead Klaufi appears for the third time and with all probability kills his main opponent with a weapon, although it is not said in the saga quite directly. After this he starts haunting the neighbourhood, and in the end his body is burned, so that he cannot walk about anymore.

It is important to notice that in this saga the revenant does not have the typical function, known from the legendary sagas. The stereotypical narrative function of revenants in the adventurous mode is to provide an opportunity for the hero to test his strength and show his courage. The revenant either guards his treasure in his mound, or he walks about, causing harm to any living being that he encounters. He is otherwise mostly unrelated to the rest of the story. Klaufi in Svarfdoela saga, on the other hand, is an important character in the story and a participant in its main events, both alive and undead. He does not oppose the protagonist, who is his kinsman; instead, he comes back from his grave to see to his revenge, then to warn his kinsman, and finally to kill his arch enemy. He therefore acts much more in the sphere of real life than revenants do in the adventurous mode. Only after these three occasions, he starts haunting the district and harming ran- 
dom people and cattle. This can be interpreted in such a way that when he has finished all his tasks in the conflicts within the society, there is no longer a place for him there, but he is unable to retreat until his body is burned, so he is forced to wander aimlessly. His previous actions, however, can be regarded as fluent continuations of the feuds in which he participated as a living man. This section of the narrative, which forms the main story line, remains entirely set in the realistic mode. The central motif is revenge, and all actions are motivated by a specific cause. The revenant's behaviour is directly based on previous events, and in turn it motivates other events, because a killing in the realistic mode always requires a revenge, and goading always leads to action. We cannot speak of a supernatural distortion of balance, because the revenant only continues to act in a previously initiated conflict.

The narrative thus employs a typical motif in an extraordinary way. As a supernatural creature, the revenant creates a specific narrative space, in which he can continue to act like he did while he was alive. Already during his life, Klaufi deviated from the common rules of life in Iceland, and as a revenant he breaks these rules even more. His narrative space bears signs of the adventurous mode, but the realistic mode's structure is retained. This draws attention to the contrast between the two modes, and the narrative can be regarded as an experiment with shifting motifs from one mode to another. Their narrative functions are transformed in the process, and therefore it is not a simple borrowing, but rather a sophisticated narrative play.

A similar modification of the supernatural elements can be found in Harðar saga ok Hólmverja, extant in the vellum manuscript AM 556 A 4to from around 1400. Here we even see a direct contrast between the uses of the same motifs in different modes within the same saga. The supernatural motifs of a revenant, a cursed object, and magic appear in both the fantastic and the realistic mode, but in different narrative functions. The shifting of the modes is circular, just like in Orms páttr Stórólfssonar.

The narrative starts in the realistic mode, with the gradual development of the central dispute. Everything is explained by a specific cause, and even predictions in the form of stanzas or dreams play the role that is typical for the realistic mode - they are firmly rooted in the story and foreshadow its continuation. The protagonist Hörðr Grímkelsson is presented as an ill-tempered and overbearing man, which explains his tense relations with everyone, including some of his kinsmen. Such explanations are also typical for the realistic mode.

The transition into the adventurous mode is, as usual, marked by a voyage to foreign lands. The heroic deeds are initiated by an oath, so they are not presented as a necessary reaction to some given situation, but rather as heroism for the sake of heroism. The protagonists decide to test their courage by breaking into a mound where a revenant guards his treasure. The transition into the fantastic mode is then marked by the encounter with the mysterious Björn, who is said to be Óðinn in disguise, and as such he represents the supernatural. The central motif of the revenant has a completely different narrative function than in the previous saga - it does not construct a continuation of a previously initiated situation, but it creates a completely new situation, which lies beyond the rules of the ordinary world. The balance is distorted when the heroes, who are supposed to overcome all challenges easily, are unable to open the mound that is protected by the revenant's magic. They open it only with the help of a supernatural force, in this case 
Óðinn's magical sword. The hero then defeats the revenant. A significant motif is the curse, which the defeated revenant casts on an armring that the hero has taken from him. The revenant states that the armring will cause the protagonist's death, as well as the death of everyone who will own it afterwards. The curse implies that the renewal of balance after the monster's defeat is not complete.

The narrative then shifts back into the adventurous mode, when the protagonist fights vikings and gains a bride; the supernatural motifs subside. Finally, the narrative returns into the realistic mode, to the local conflicts in Iceland. When the protagonist is outlawed, it is presented as a consequence of his reckless behaviour and conflicts with powerful men. Even the magic in the realistic mode is moderate and firmly rooted in the story - three women who are generally known to be accomplished in witchcraft use their arts to protect their property from being stolen by the outlaws. The purpose of the witchcraft is entirely rational, and it is presented as rather dubious trickery: it does not make any real changes, it only makes things appear differently to the eyes of men. It affects only the hero's companions, but not the hero himself, so he is able to see through the trickery and avert its effects simply by cleverness and courage. This situation is quite different from the encounter with the revenant in the fantastic mode, where the supernatural creature's powerful magic disrupted the balance and required a supernatural counteraction. The saga thus plays with the supernatural motifs and their narrative functions in the different modes.

Significantly, the curse from the previous episode has no direct or demonstrable effect on the action. The motif of the cursed armring reappears only at the saga's end, and even then its function in the narrative is symbolic, rather than supernatural. Three men are killed while they are wearing the cursed armring, but the causes of the killings are described in detail and shown to be firmly rooted in the local social relations and disputes. We can thus not say with certainty whether the armring caused the deaths or not. The armring can rather be symbolic of the bad luck that befell these men, in a similar way as dreams can be symbolic of bad luck in the classical sagas.

In this case we can speak of the concept of the fantastic as defined by Todorov: "There is an uncanny phenomenon which we can explain in two fashions, by types of natural causes and supernatural causes. The possibility of a hesitation between the two creates the fantastic effect" (Todorov 26). Todorov's definition of the fantastic as a genre is too limiting, because it isolates the supernatural elements and does not fully account for the wide range of functions that they can have in literature. If we, however, understand his definition as one of the many possible concepts of the fantastic, we can use it for formulating a specific type of narrative play.

In the final section of Harðar saga, the reader may hesitate about whether the three men died only due to the conflicts described in the text, or whether the curse had some influence on the matter. The saga offers no final answer, so the fantastic in this sense is retained until the end. Supernatural motifs can be employed in such a way only in the realistic mode, because in the other modes the supernatural cause would be unquestionable. But even though the realistic mode is dominant in the classical sagas, this type of narrative play cannot be found in them to the same extent. It is specific for the post-classical texts, and it is underlined by the contrast with the fantastic mode within the same saga.

The cursed armring has a demonstrable effect on the action only in one scene at the end of the saga, in which two sorceresses kill each other because of the armring, since 
they both want to gain it by any means. The texts also states that both women's graves were haunted afterwards, but the armring was never found again. This implies that the sorceresses probably became revenants or ghosts, because they had died violently and could not find peace; that way the armring returned into the supernatural world, where it had originally come from. The boundary between the worlds was finally closed and the cursed object could no longer disrupt the human world's balance. This is a final conclusion of the episode narrated in the fantastic mode, which serves to remind the audience of the mode shifting right before the saga's end.

Finally, we can turn to Grettis saga, a text extant in several 15th- and 16th-century vellum manuscripts (AM 556a-b 4to, AM 152 fol., AM 551 4to, AM 571 4to, DG 10 fol.), where it is combined either with other outlaw sagas, or with some of the more supernatural post-classical texts, as well as legendary sagas and saga romances. The saga is believed to have been originally composed in the early 14 th century. This text is probably the best known post-classical saga, and the only one that has received considerable scholarly attention (Arnold 219-221). Nevertheless, some scholars have criticized it for its inclination toward the supernatural (Hume 1974, 269-270), as well as for its narrative structure, which they viewed as episodic and lacking a "dramatic centre" (Clover 20). Here we will attempt to demonstrate that the saga's structure is consistent, and that its changeability can be explained as deliberate shifting of the narrative modes.

The saga's beginning, dealing with Grettir's ancestors and with his early youth, is set in the realistic mode. All the conflicts are explained by causes rooted in the social structures, mainly power struggles. The purpose of this long introduction is to describe the conditions in which the protagonist's life will be set.

The shift to the adventurous mode is marked by the change of environment when Grettir first sails to Norway. He finds out about a mound where a revenant guards a treasure, and he breaks into the mound for no particular reason, only in order to test his strength and show his courage. He also defeats a band of berserkers, and as a reward he receives the sword from the mound. Typically for this mode, the protagonist's heroic deeds do not have any direct effect on his future, he only gains glory and a reward. The supernatural elements constitute only individual episodes in which the hero shows his abilities, and they do not disrupt the story's balance. In this part of the story Grettir's heroism is useful to the society, he is a clearly defined defeater of external evil that threatens the central narrative space. However, Grettir also acts recklessly, he kills several men in insignificant disagreements, and he is forced to leave Norway.

Back in Iceland, Grettir looks for an opportunity to use his strength in a similar way, and he seems to find it when he encounters the undead Glámr. The encounter with the revenant marks a transition into the fantastic mode, as the balance is disrupted by a supernatural intervention. The revenant threatens the people and nobody but Grettir dares to oppose him. While Grettir is fighting Glámr, he is cursed by the revenant before he manages to behead him. This time the motif of the undead does not constitute only a passing episode, as the fight changes Grettir permanently, and the revenant's curse probably has an irreversible effect on Grettir's life.

When the revenant disappears, the narrative returns into the realistic mode, but the balance is not restored completely, because there is no supernatural force in the counteraction. The change that Grettir undergoes after the fight denies the hero's victory over the 
monster, and we can assume that it also hinders him in entering a clearly defined heroic position ever again. Grettir makes another attempt at establishing himself in Norway, and he keeps trying to apply his strength to useful purposes, but due to his ill luck he is not accepted at the royal court and is falsely accused of a crime. He does not succeed in returning into the heroic world of the adventurous mode, in which he could live a fulfilling life as a monster slayer.

Here we can again see a trace of the fantastic as defined by Todorov, although it is less striking than in Harðar saga. Grettis saga, just like Harðar saga, leaves no doubt as to whether the encounter with the revenant actually happened, which is understandable, since the encounters occur in the fantastic mode. Both sagas, however, leave some room for hesitation as to how much the revenant's curse actually affected the protagonist's future. ${ }^{5}$ In Grettis saga the narrative makes a much stronger impression of Grettir's ill fate being a consequence of the curse, because it is clearly stated that he honestly tried to use his strength for beneficial purposes. Still, we may hesitate about whether the unlucky accusation could have been caused by Grettir's troublesome character and bad reputation alone. The curse's effect is not accompanied by any supernatural occurrences, and we may see it as a possibility that people chose to blame Grettir simply because he was not unlikely to be guilty, or because they envied him his strength. In this sense the hesitation is present also here. As we have seen, such a type of narrative play is not typical for the classical sagas or for the adventurous mode, in which the supernatural motifs constitute only passing episodes. In the post-classical texts, on the other hand, such narrative experiments are much more prominent.

After his failed journey to Norway, Grettir returns to Iceland and spends the rest of his life as an outlaw, a symbolic embodiment of the disbalance caused by the supernatural intervention. Grettir belongs neither within the human world defined by the law, nor within the non-human world of trolls and monsters. He is sometimes compared to a troll in the sense of an anti-social force, but sometimes he kills trolls that threaten the human society. He inhabits the liminal space between the human and the monstrous, and he remains ambiguous - he cannot return to the society, nor can he be killed by normal human methods. When he is finally killed with the help of magic, the ambiguity is retained: the outlaw represents an anti-social force, but so does the sorceress who causes his death. Both are liminal figures, the outlaw lingers between the society defined by law and the lawless wilderness, the sorceress lingers between the natural and the supernatural. Again, the supernatural element - the magic - is essential for the main story line. Such a connection between the supernatural and the essential plot twists is typical for the post-classical sagas, in which the various combinations of the mimetic and fantastic impulse are significant for the overall construction of the text.

Apart from its plot-related function, the shifting of the modes in the post-classical texts also constitutes a moral aspect of the saga. In the adventurous mode the protagonist is an unambiguous hero with no moral dilemmas, but on the border between the fantastic and realistic mode he faces various moral dilemmas, and his evaluation in the narrative is also much more complex. When Grettir kills the dangerous trolls as an outlaw, he risks

5 Todorov's theory of the fantastic has already been associated with Grettis saga by Vésteinn Ólason (14-15), but out of context of the saga's overall structure and meaning. 
his life for the society that has rejected him. Unlike the celebrated heroes, he does not gain anything by his prowess, not even the right to return into the society, and therefore his heroism has a deeper moral dimension and provokes questions that reach beyond the actual story line.

\section{5.}

It has been attempted here to show that the central difference between the classical and post-classical sagas of Icelanders consists in the narrative principles that form their structure and meaning. The age of origin is not decisive for the distinction between the two types of sagas; Daniel Sävborg (2012a) has convincingly argued that not all the sagas regarded as post-classical were composed after 1300. The post-classical sagas were surely not among the earliest saga texts that were written down, but it also makes little sense to assume that there was a sharp dividing line between when the classical and post-classical sagas were composed. It is much more likely that there was a time, probably the second half of the 13th century, when both types of sagas were composed simultaneously, while the post-classical sagas continued to be composed also later (Sävborg 2012a, 51-52). This is, however, not a reason to disregard the distinction between the classical and post-classical sagas of Icelanders, as the dating of the texts is not decisive for their inclusion into one of the groups.

The concepts of narrative modes and narrative space can be helpful in analysing the sagas' structure and meaning, as they shed light on the narrative roles of individual elements or motifs, so that rather than simply evaluating the number and kind of such elements within a text, we can evaluate their function. All the post-classical texts that have been studied here show a substantial degree of narratological sophistication in terms of the shifting of narrative modes and the work with narrative space. They differ from their classical counterparts by the different and more varied narrative functions of the supernatural elements and a more creative approach to the narrative structure. As we have seen, the post-classical narratives do not just randomly combine motifs from the classical sagas of Icelanders with motifs from the legendary sagas and foreign romances. Instead, they consciously work with them and modify them according to the narrative modes that prevail in different parts of the texts.

These texts with their complex and unique way of combining the narrative modes can therefore be seen as cases in point in arguing that the post-classical narratives of Icelanders form a specific category of texts, rather than being less valuable exemplars of the sagas of Icelanders. Instead of regarding them as inferior to the classical texts or as products of a literary decline, we can perceive the post-classical narratives of Icelanders as advanced - and in many ways modern - works of narrative sophistication.

Furthermore, it is too limiting to see the supernatural character and open fictionality of the texts as a sign of disinterest in the social concerns. Instead, we can perceive the openly fictional texts as conceptualizations of the problems and values that were current in the society which produced the texts. I do not agree with Sävborg's opinion that the development toward the post-classical narratives was not related to the political development of the society (Sävborg 2012a, 52-53). The possible earlier dating of some of the texts does 
not exclude the connection, because the decisive political change, the union with Norway, took place in 1264, not after 1300. I believe that the changes in the social system were the main impulses for the increasing significance of the post-classical narrative principles, but the transition was gradual and the older type of narratives continued to be produced for some time after the upswing of the new one. Moreover, the central elements of the post-classical sagas' narrative modality were not entirely new to Old Norse culture.

The fantastic mode, far from being a late or imported structure, is the original structure of Old Norse mythology, which is based on the conflict between the forces of order and chaos. These forces are clearly separated from each other and defined as internal and external respectively. In individual mythological stories the balance is disrupted by the forces of chaos, represented usually by the giants or by Fenrir or Miðgarðsormr, and supernatural counteraction must be performed by the gods, so that the balance can be renewed. Although the mythology in its extant form is not complete and was written down by scribes who no longer regarded it as a divine truth, we can assume that its essential structure is preserved in its original form and that it is a conceptualization of the struggles that the Scandinavians were dealing with - the external threats to the society, whether it was raiders and plunderers or the uncontrollable and unpredictable natural forces.

In the 12th- and 13th-century Iceland these concerns became secondary, as the society was increasingly torn by internal conflicts. In the transitional stage between de-centralized and centralized power, the social structures became unstable and the society could no longer present itself as a unified whole, ready to face external threats. It was the internal threats of endless power struggles and bloody attacks that the people were most worried about. The classical sagas of Icelanders, set in the realistic mode, reflect such concerns, because, although they deal with much older events, they were mostly written down during the Sturlung Age. The texts deal primarily with conflict and reconciliation, and they focus on the principles of maintaining social balance, or on the principles of gaining, maintaining, and losing power. The saga feud with the gradually increasing violence is a typical example of the linear structure of the realistic mode: a conflict gradually develops into an armed clash, this is followed by a violent retaliation that leads to a killing and to a subsequent vengeance killing, finally followed by negotiation and reconciliation. This structure reflects the most pressing social concerns of the Sturlung Age, which were connected to the society's internal struggles.

After Iceland had accepted Norwegian royal rule in 1264 , the social instability subsided. Admittedly the situation was not ideal, as new complications arose from a dispute over church property between ecclesiastical and temporal power. These conflicts, however, involved ink on parchment, rather than blood on the battlefield, and they followed generally understandable rules of the game, in which each party defended its clearly formulated interests. The new lawbooks issued by King Magnús Hákonarson and accepted by the Icelanders in 1271-1274 and in 1281 regulated the disputes and introduced executive power, which transformed conflicts from the private to the public sphere (see Wærdahl). Blood revenge still existed, but it was no longer among the society's essential aspects (see Porláksson). ${ }^{6}$ The society could again feel united against external threats.

6 The social background of the reduced importance of feud in the sagas has already been pointed out by Véstein Ólason (10 and 20). 
Such tendencies were reflected in the post-classical sagas of Icelanders, in which the fantastic mode, with its internal sphere of order and external sphere of chaos, became dominant. That way the narratives, broadly speaking, returned to the mythological mode.

If we want to place the marginal figures typical for the post-classical texts - such as outlaws, sorceresses, and reckless fighters - within the mythological paradigm, they must stand in the place of Loki. This mythological character belongs neither within the world of the gods, nor that of the giants, and he both threatens the gods and helps them. This type of figure embodies the idea that the boundaries between "order and chaos" or "good and evil" or "internal and external" are, despite their importance, not clearly delimited, as there can be a thin line between both spheres.

In a broader perspective, such a mythological paradigm can reflect some of the essential social aspects of the late 13th- and 14th-century Iceland. The society was still primarily defined by the law, but it was no longer the only element of distinction between "our own" and "the other". Some of the boundaries could intersect and were not necessarily clear. Despite the reduction of complicated disputes, the post-classical society was no less complex, and it was not based on simplified dichotomies between good and evil. Just like the myths, the post-classical saga literature emphasizes the boundaries between "internal and external", but it does not portray them as unambiguously and unchangeably given.

We can therefore not accept the idea of "a repudiation or denial of social complexity" in the post-classical sagas and poettir (Arnold). The increasingly open fictionality of the texts, created by their narrative form, does not mean that the texts turned away from reflection of reality. There is no straight boundary between social commentary and supernatural elements, as both aspects are inseparable, and it is just the combination of the mimetic and fantastic impulse that enables the interpretation of society that is presented in the texts. The presence of "other worlds" does not lead to sheer fabulation, but it serves as a means of opening a discussion of various social concerns. The space for such a discussion opens itself due to the deliberate contrast between different narrative modes, so the post-classical narratives reflect the pressing social concerns of their age in a different way than the classical sagas, but with the same intensity and diversity. It is only the focus of interest that changed, because the society itself had been transformed. ${ }^{7}$

\section{BIBLIOGRAPHY}

Arnold, Martin. The Post-Classical Icelandic Family Saga. Lewiston: Edwin Mellen Press, 2003.

Cardew, Phil. "The Question of Genre in the Late Îslendingasögur: A Case Study of Porskfirðinga saga." Sagas, Saints and Settlements. Ed. Gareth Williams and Paul Bibire. Leiden: Brill, 2004. 13-27.

Clover, Carol. The Medieval Saga. Ithaca: Cornell UP, 1982.

Einarsson, Stefán. A History of Icelandic Literature. New York: Hopkins, 1957.

Faulkes, Anthony. "Harðar saga." Medieval Scandinavia: An Encyclopedia. Ed. Phillip Pulsiano and Kirsten Wolf. New York: Garland Publishing, 1993. 269.

Gordon, Eric Valentine. An Introduction to Old Norse. Oxford: Clarendon Press, 1957.

Hallberg, Peter. The Icelandic Saga. Lincoln: U of Nebraska P, 1962.

7 This research was supported by the Charles University project Progres 3 (Q07), Centre for the Study of the Middle Ages. 
Hallberg, Peter. Den isländska sagan. Stockholm: Bonnier, 1964.

Hume, Kathryn. "The Thematic Design of Grettis saga." The Journal of English and Germanic Philology 73 (1974): 469-486.

Hume, Kathryn. Fantasy and Mimesis: Responses to Reality in Western Literature. New York: Methuen, 1984.

Jakobsson, Ármann. "History of the Trolls? Bárðar saga as an Historical Narrative." Saga-Book 25 (1998): 53-71.

Jakobsson, Ármann. “The Good, the Bad and the Ugly: Bárðar saga and Its Giants.” Medieval Scandinavia 15 (2005): 1-15.

Nordal, Sigurður. Íslenzk menning I. Reykjavík: Mál og Menning, 1942.

Nordal, Sigurður. Litteraturhistorie: Norge og Island. Stockholm: Bonnier, 1953.

O'Connor, Ralph. "Astronomy and Dream Visions in Late Medieval Iceland: Stjörnu-Odda draumr and the Emergence of Norse Legendary Fiction." Journal of English and Germanic Philology 111 (2012): 474-512.

Ólason, Vésteinn. “The Fantastic Element in 14th-century Îslendingasögur.” Gripla 18 (2007): 7-22.

Sävborg, Daniel. "Avstånd, gräns och förundran: Möten med de övernaturliga i islänningasagan." Greppaminni: Rit til heiðurs Vésteini Ólasyni sjötugum. Ed. Margrét Eggertsdóttir. Reykjavík: Hið íslenska bókmenntafélag, 2009. 323-349.

Sävborg, Daniel. “Den efterklassiska islänningasagan och dess ålder.” Arkiv för nordisk filologi 127 (2012a): 19-57.

Sävborg, Daniel. "Fornaldarsagan och den efterklassiska islänningasagans uppkomst." The Legendary Sagas: Origins and Development. Ed. Annette Lassen, Agneta Ney, and Ármann Jakobsson. Reykjavík: U of Iceland P, 2012b. 232-250.

Schach, Paul. "Gull-Póris saga." Dictionary of the Middle Ages. Vol. 6. Ed. Joseph Reese Strayer. New York: Scribner, 1985. 27.

Sveinsson, Einar Ólafur. The Age of the Sturlungs: Icelandic Civilisation in the Thirteenth Century. Ithaca: Cornell UP, 1953.

Sveinsson, Einar Ólafur. Dating the Icelandic Sagas: An Essay in Method. London: Viking Society, 1958.

Todorov, Tzvetan. The Fantastic: A Structural Approach to a Literary Genre. Ithaca: Cornell UP, 1975.

Wærdahl, Randi Bjørshol. The Incorporation and Integration of the King's Tributary Lands into the Norwegian Realm c. 1195-1397. Leiden: Brill, 2011.

porláksson, Helgi. "Konungsvald og hefnd." Sagas and the Norwegian Experience. Ed. Jan Ragnar Hagland. Trondheim: Norges teknisk-naturvitskaplege universitet, 1997. 249-261.

Lucie Korecká

Charles University

E-mail:lucy.korecka@seznam.cz 